\title{
General Program of the Committee on Documentary Reproduction, American Historical Association'
}

Dr. Erickson, University of Illinois, is chairman of the Committee on Documentary Reproduction, American Historical Association.'

$\mathrm{T}$ HIS IS THE BROAD OUTLINE of the program on which the committee has been working during the past few years. The Committee on Documentary Reproduction was created in I 946 as a special committee of the Committee on Historical Source Materials, the latter under the chairmanship of Dr. Herbert A. Kellar. Upon the discontinuance of the parent committee in 1947, the Committee on Documentary Reproduction became a basic committee of the Association and has functioned since in that status.

The major objectives of the committee are (I) to utilize the established technical media of documentary reproduction to make scarce, costly, and generally inaccessible basic source materials available to scholars; and (2) to whip the frightful difficulty of getting manuscripts published by promoting a program of low-cost microprint publication, together with a broad distribution of the microprinted editions.

Within the scope of basic source materials are included national and state legislative, executive, and judicial materials, newspapers and periodicals, and miscellaneous selected documentary materials, both official and nonofficial in character. In other words types of

1 This paper was read before the session, "The $\mathrm{Mi}$ crofim Program," December 29, 1952 at the Annual Meeting of the American Historical Association in the Mayflower Hotel, Washington, D.C.

The members of the Committee on Documentary Reproduction of The American Historical Association are: Austin P. Evans, Columbia University; C. W. de Kiewiet, University of Rochester; J. Harry Bennett, University of Texas; Lawrence A. Harper, University University of Texas; Lawrence A. Harper, University Library; Richard W. Hale, Jr., Wellesley College; Loren C. Mackinney, University of North Carolina; Warner F. Woodring, Ohio State University; and Edgar L. Erickson, University of Illinois, chairman. sources that serve the needs of the greatest number of scholars.

Source materials are being made available to scholars as a result of four different but closely related operations: (a) By a program of republication in microprint of printed basic sources; (b) By utilizing Fulbright research scholars to obtain microfilm copies of selected foreign manuscript materials; (c) By depositing the master negatives of these materials in the Library of Congress for use either there or through interlibrary loan or for the purchase in positive microfilm duplication by other libraries, when this practice is not ruled out by the holders of the original manuscripts; and (d) By publishing the results of the above operations so that scholars will know about the sources acquired.

With these general objectives and the operations by which these objectives are being achieved in mind, let us next consider further the operations.

With respect to the microprint republication program the committee is placing sources within the immediate reach of scholars by making it possible for libraries to purchase low-cost microcopies of basic printed documentary collections. At the outset the committee decided that the process employed in large scale republication must meet the following essentials: the microcopies must fulfill the requirements of permanent records, i.e. they must have a permanence of 300 years or more; they must be low in cost; and they must be easy for the researcher to use and for the library to store. In our opinion microprint, produced by the Readex Microprint Corporation of Chester, Vermont, best meets all of these qualifications. Microprint is a printing press operation in which 100 pages of text, arranged in a uniform decimal pattern, are printed in carbon printers' ink on 9 by 6 inch cards that possess the properties of per- 
manent record paper as specified by the $\mathrm{Na}$ tional Bureau of Standards. Because of the economy of a printing press operation microprints are produced at a considerably lower cost than other forms of microreproduction. Because of the decimal arrangement of text pages on the card, a reader can insert a card in the projector and locate a given page in a matter of twenty seconds; and because the fundamental qualities of microprint are the same as those of books, the cases in which the cards are issued may be stored on ordinary library shelves under the same temperature and humidity conditions as books.

Microprint marks a veritable revolution in printing. The process resulted from 20 years of research and experimentation, with the usual burdensome expense and heartbreaking series of failures and partial successes before the final goal was reached. The man who perfected this process that will mean so much to the historian and to the public at large is Albert Boni, publisher, of New York. Twenty years ago he gave up his regular publishing business and devoted his time to the development of microprinting. Think of the problems he encountered in fashioning a printing plate for text pages reduced 300 times that would print a microcopy as sharp in definition as that of microfilm; and think of the problems of ink control and technical adjustments of the printing press that he had to solve for the successful use of that plate. Mr. Boni deserves a place in history along with the other great inventors. His achievement is a personal one; it has not been the product of a subsidized research laboratory. And what is more the motivating force behind his long years of research was his desire to bring literature of mankind within the reach of people in their own homes. Never have I met a more genuinely philanthropic person, and as chairman of a committee that is utilizing the process that $\mathrm{Mr}$. Boni developed to reprint significant historical collections, I must publicly acknowledge the debt that historians of the future will owe to him.

The committee has sponsored one large microprint republication project and has others under consideration. The microprinting of the British House of Commons Sessional Papers for the igth century is now reaching its final stages. This project involves about 6000 volumes of approximately 4,000,000 pages. The collection is composed of upwards of 80,000 separate papers bound in annual sessional series, and republication involves heavy preparatory work of collating to establish a complete set of the papers and a complete text of the individual papers, and of editing to insure an intelligible arrangement of the papers within the microprint decimal pattern; and republication also involves final proofing of the entire collection to insure against illegibility and errata that arise from slips in the editing, the photographing, and in the composition of plates. Aside from significant financial aid by the University of Illinois in the proofing of the microprint edition, the project has been entirely self-sustaining through sales to libraries. Prepublication subscribers are obtaining the Ioo years of volumes for about $\$ 5000$ or about $\$ .75$ a volume. Single volumes of the original papers have retailed for about $\$ 5.00$ i a volume when they could be found; and the committee estimated that a microfilm edition of the collection would have cost at least $\$ 25,000 .^{2}$ The microprint edition will probably be the only complete collection in existence of the papers listed in the official composite indexes for the century.

If the demand warrants, the early sessional papers and those for the 2oth century, will be microprinted; as also will the parliamentary Journals and the parliamentary Debates.

The committee is also sponsoring a project to microprint a large collection of carefully selected Russian materials that was compiled by Professor F. S. Rodkey of the University of Illinois in consultation with a large number of other scholars in Russian history. The project must have 50 subscribers if it is to be executed. Within the past two weeks letters have been sent to nearly 200 libraries inviting participation, and we are now awaiting the results of this canvass. The priority list was compiled with the view to keeping the cost within a $\$$ Iooo limit. To give some idea of the values that subscribers would receive for their money in these choice Russian sources I can state that one title alone in the 27 on the select list is quoted for sale at $\$ 160$. Professor Rodkey is the editor in charge of the project, and he has with him here at the meeting extra priority lists for persons interested in seeing them. The committee also invites your support back

2 This estimated cost in microfilm includes the collation and editing costs that total over $\$ 60,000$, and that are being paid by the Readex Microprint Corporation. It does not include, however, the cost of final proofing which will amount to about $\$ 17,000$ before it is completed. 
on your campuses in helping to enrol your respective libraries as active participants in the project.

Professor Austin P. Evans of Columbia University is endeavoring to do something about the microprint republication of "Out of Print Books" in the medieval field.

The Readex Microprint Corporation and the Government Printing Office have announced a project to microprint the 12,000 non-depository U.S. government documents that are published yearly but that are not included in the documents of the depository collection that is distributed to libraries. In the non-depository list are the publications of the Atomic Energy Commission, the Federal Trade Commission, and a host of other important agencies. It is my belief that in the matter of a few years nearly all government publications will be circulated to libraries in microprint only. This change would effect a savings of millions annually to the government in printing costs and to the libraries in space saving and cataloging costs. The committee is proud to know that by its pioneer operations with the Sessional Papers a vast new frontier has been opened in the field of government publications. Likewise we are glad to note that our colleagues in English are following the lead of historians and are microprinting all plays published in English prior to I 830 .

Microprint also lends itself to the field of original publication. This can best be initiated in the field of thesis publicaton. For $\$ 100$ a student could have his thesis microprinted and circulated without further cost to 200 libraries. The steps necessary to establish this mode of original publication are quite simple: Graduate colleges should first recognize microprint publication as a legitimate form of publication. Once this recognition is gained, publication of non-thesis studies would soon gain general acceptance. The Readex Company could help the cause by producing a lowcost projector that could be placed in a living room or study as an article of furniture and by issuing a library of choice literature that would appeal to the average person. Mounted on a portable base and an adjustable arm such a projector could be rolled into place before the reader lounging in his favorite chair and used with the comfort required for leisure reading. For a cost that would make the present drug store editions of literature seem expensive, a huge library of microprint editions could be made available to the average home.

Next let us turn to the phase of the committee's program that is based on the utilizing of Fulbright research scholarships for obtaining research materials in foreign archives. This phase of the committee's program is especially being considered in this session.

Our activity apropos of the Fulbright program started in 1947 when the Fulbright Board was formulating policy with respect to its educational program. At that time with encouragement from both Senator Fulbright and the Department of State, the committee made an all-out effort to get an annual assignment of Fulbright funds from each of the 28 countries involved, that could be used to obtain microcopies of selected basic source materials. In our proposal to the Fulbright Board we emphasized that the assignment of a percentage of funds for microcopies of foreign documents would benefit a far greater number of American scholars than would the expenditure of similar amounts for sending scholars abroad. We believed that a liberal interpretation of the Act would justify the use of a part of the funds for microcopying activities, and that with funds so assigned we could undertake large-scale microcopying projects abroad. Our proposal was supported by our Association and its Pacific Coast Branch, the Mississippi Valley Historical Association, the Library of Congress, the American Political Science Association, the American Sociological Society, the Committee on Renaissance Studies of the American Council of Learned Societies, the Association of Research Libraries and the American Economic Association. In the final determination of policy, however, the Fulbright Board went only part way in granting the committee's requests. They provided for research scholarships as part of the Fulbright educational program, and made scholars with applications embracing microfilming projects, indorsed by the committee on the Library of Congress, eligible for research scholarships. While this was only a half-success, the research scholarships together with assistance from the Library of Congress have made it possible for us to carry out limited microcopying activities abroad. We do not believe that the considerable missionary work of the committee in getting research scholarships included in the Fulbright program is generally 
appreciated by the many recipients of these awards.

Since the allowance for technical expenses to a Fulbright research scholar is limited to $\$ 500$, and even that amount is not always forthcoming, the microcopying activities of the scholars who have participated in our program have been governed largely by the types of materials that the Library of Congress was, in a position to purchase from its limited funds. These materials fall into three categories: catalogs and inventories of manuscript collections, legal materials, and documents related to American history. Nearly all of the projects that have been jointly sponsored by the committee and the Library of Congress have been based on one or the other of these categories. In all cases, however, the microfilms obtained will be of value to historians, and the committee wishes to thank the Library of Congress for its splendid cooperation. What has been accomplished thus far is only a sample of the manner in which the historian can be of assistance to the library and the library to the historian.

Without stealing the ammunition of the speakers that follow me, I must say a few words about the various country programs. At the outset special committees were established for each of the Fulbright countries. The committees are to be found in the Annual Proceedings of the Association for $1947 .{ }^{3}$ Some of these committees have done very excellent work and have achieved positive results; others have been defeated by circumstances in specific foreign countries that were beyond their control; and some have not succeeded in shaking off the inertia of lassitude.

Two committees in particular prepared remarkable programs that were strangled by the ever-grasping tentacles of communism. That for Finland prepared by Professor John I. Kolehmainen, Heidelberg College, had to be suspended because Finland has never implemented the Fulbright program. It may be that conditions will soon permit something to be done to repay Professor Kolehmainen for the commendable plans that he made for microfilming Finnish sources. Similarly a wellconceived program for China that was framed by Dr. Arthur W. Hummel, Division of Orientalia, Library of Congress, had to be

s See "Committee on Documentary Reproduction," Annual Report of the American Historical Association for the Year 1947, Vol. I, Proceedings, pp. 57-64. shelved, and I can see no hope for its resumption in the unpredictable future.

On the other hand, active programs are in progress for France, Italy, Greece, Austria and the Philippines. While I shall leave comment on the first three of these countries to the other speakers, I do want to commend Professor Richard W. Hale, Jr., Professor Loren C. MacKinney, and Professor Peter Topping for the initiative and good judgment they have shown in developing their respective countries. In the case of Austria developments are proceeding in both the medieval and modern fields. Professor George B. Fowler, University of Pittsburgh, spent the year 195 I52 in Austria where with financial aid from the American Philosophical Society he microfilmed a large number of unpublished catalogs and inventories of medieval collections of several of the forty-odd Austrian monasteries. This work we hope to continue in subsequent operations under Professor Fowler's direction. Professor Ralph H. Lutz of Stanford University has cleared the way for the microfilming of Austrian national and provincial archival materials, and we hope that a suitable candidate can be found for initiating work in this field during the coming year.

Edgar B. Wickberg of the University of California is now in the Philippines where he is surveying the archival records with the view to preparing a microfilming project embracing materials within the categories that are desired by the Library of Congress.

As we are able to get funds that can be utilized for microcopying operations, additional country programs will be opened. As I see it the best solution to the matter of funds would be for the research libraries to contribute a small percentage of their annual book budgets to a common fund that could be expended for selected basic source materials in foreign archives. By their contributions libraries would purchase a loan service from the Library of Congress acting in the capacity of a central depository for the acquired foreign documents. A few years ago the committee and the Library of Congress submitted just such a proposal to the Research Libraries but as yet they have not taken final action on it.

Time does not permit me to expand on the matter of interlibrary loan of materials in microform, and on the publication of the re-

(Continued on page 316 ) 
the subcommittee that much of the objection to microfilm is psychological. No tests have been made to learn how valid the objections expressed most often really are. No doubt, a contributing cause to the aversion for film is that the microfilm facilities are substandard. Only 3 of 75 libraries indicated their facilities were excellent and in each of these there was a high percentage of satisfied patrons. Certainly, there is great need for educating to film use not only the public but also librarians, many of the latter being apathetic and even daunted because some slight mechanical sense is required.

Just how far libraries will go in using film in preference to binding, no one can say for sure. The time must pass to permit a thorough comparison of the different types of micro-reproduction. No doubt, the five year experiments being conducted with microfilm by several college libraries will go far in providing necessary information for a decision. Possibly, by 1960 many librarians will have taken a definite stand, but of course, many others will still be waiting and watching. However, until there is developed a form of reproduction which will suit the library clientele better, and yet offer as many advantages as microfilm, at least for much of the periodical literature, there seems no better solution to the problem of costly storage.

\section{American Historical Association}

\section{(Continued from page 306)}

sults of the various microcopying projects. It is the desire of the committee to promote the principle of a centralized depository in the Library of Congress in connection with an inexpensive interlibrary loan service. This principle the Librarian of Congress has indorsed.

But interlibrary loan service to be effective must be supplemented by a publication of the micro-acquisitions, both old and new, of the Library of Congress so that scholars will know what is available. The committee is endeavoring to publicize the results of its programs by printing the checklists of materials obtained and deposited in the Library of Congress in the Annual Report of the American Historical Association, Vol. I. Proceedings as supplements to the annual committee reports. ${ }^{4} \mathrm{We}$

4 For checklists submitted by research scholars jointly sponsored by the Committee on Documentary Reproduction and the Library of Congress see "Committee on Documentary Reproduction," Annual Report of the American Historical Association for the Year I951; 1952, erican Historical Association for the Year
Vol. I, Proceedings (publication pending) are encou raging our jointly sponsored research scholars to submit for publication in the American Archivist articles related to their work in foreign archives that will be helpful to colleagues who may follow them in work abroad. ${ }^{5}$ Attention should also be called to the Library of Congress Quarterly Journal of Current Acquisitions for information regarding the microfilm holdings of the Library of Congress. I wish in particular to cite an article in the November, 1952 issue of the Quarterly Journal by Dr. Lester K. Born, entitled "Microreproductions" for an excellent summary of the Library of Congress holdings in micro-materials, as a good start for learning of the vast resources that already have been acquired by the library and that are available to the scholar.

\footnotetext{
- For articles already published see Rice, Howard $\mathrm{C}_{\text {; }}$ Jr., "The Paris Depository for Notarial Archives," American Archivist, 14:99-104, April, 195I ; Topping, Peter. "The Public Archives of Greece," American Archivist, I 5 :249-257, July, 1952.
}

\section{Suggestions for ACRL Publications Committee}

One of the functions of the ACRL Publications Committee is to recommend needed booklength studies in the college and university field to the ALA Publishing Department. There are, undoubtedly, many good ideas for books in the minds of ACRL members, and, in order to get them discussed and presented to the ALA Publishing, such requests should be channeled to the ACRL Publications Committee. ACRL members who have suggestions are requested to send them to Lawrence S. Thompson, chairman, ACRL Publications Committee, University of Kentucky Libraries, Lexington, Kentucky. 